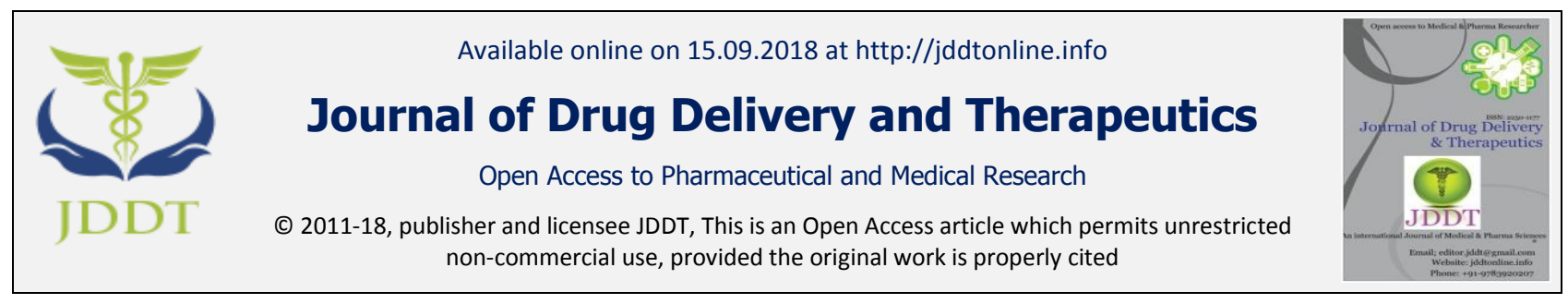

Open $\odot$ Access

Review Article

\title{
MEDICINAL PLANTS FOR THE TREATMENT OF SNAKEBITES AMONG THE RURAL POPULATIONS OF INDIAN SUBCONTINENT: AN INDICATION FROM THE TRADITIONAL USE TO PHARMACOLOGICAL CONFIRMATION
}

\section{Ramaswamy Malathi*, Duraikannu Sivakumar, Solaimuthu Chandrasekar}

Research Department of Biotechnology, Bharathidasan University Constituent College, Perambalur district, Tamil Nadu state, India, Pin code -621107

\begin{abstract}
Snakebite is one of the important medical problems that affect the public health due to their high morbimortality. Most of the snake venoms produce intense lethal effects, which could lead to impermanent or permanent disability or in often death to the victims. The accessible specific treatment was using the antivenom serum separated from envenomed animals, whose efficiency is reduced against these lethal actions but it has a serious side effects. In this circumstance, this review aimed to provide an updated overview of herbal plants used popularly as antiophidic agents and discuss the main species with pharmacological studies supporting the uses, with prominence on plants inhibiting the lethal effects of snake envenomation amongst the rural tribal peoples of India. There are several reports of the accepted use of herbal plants against snakebites worldwide. In recent years, many studies have been published to giving pharmacological confirmation of benefits of several vegetal species against local effects induced by a broad range of snake venoms, including inhibitory potential against hyaluronidase, phospholipase, proteolytic, hemorrhagic, myotoxic, and edematogenic activities. In India, a variety of herbal plants are used to cure against the snakebites and other poisonous bites, used either in alone or in combination with other herbal agents. The present study was designed to formulate an attempt to bring together information on medicinal plants that are grown and used for snakebite treatment in India. From a variety of literature sources, data have been compiled with prominence on the plants, family, parts used, etc., depending on the availability of information.
\end{abstract}

Key words: snakebite, India, traditional medicine, medicinal plants, venom, remedy, snakebite treatment.

Article Info: Received 21 May, 2018; Review Completed 26 July 2018; Accepted 18 Aug 2018; Available online 15 Sep 2018

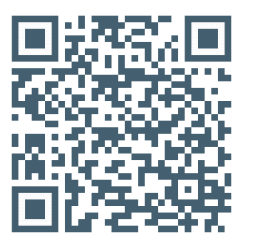

\section{Cite this article as:}

Ramaswamy M, Duraikannu S, Solaimuthu C, Medicinal plants for the treatment of snakebites among the rural populations of Indian subcontinent: An indication from the traditional use to pharmacological confirmation, Journal of Drug Delivery and Therapeutics. 2018; 8(5):62-68 DOI: http://dx.doi.org/10.22270/jddt.v8i5.1799

Dr. R. Malathi, Assistant Professor and Head, Department of Biotechnology, Bharathidasan University Constituent College, Kurumabalur, Perambalur, Tamil Nadu state, India-621 107

\section{INTRODUCTION}

Historically, humans have depended on nature to provide for their fundamental needs, namely food, clothing, medicines, and natural healing remedies. This reliance led the aboriginal people living in synchronization with nature to develop a system of knowledge about plants, which play several important functions in human life (Nasab Khosravi, 2014; Ody, 1993; Rashid et al., 2015). The World Health
Organization estimates that about $80 \%$ of the world's population in developing countries depends on plants for the management of a variety of diseases, because of the lack of modern healthcare services (Calixto, 2005; WHO, 2002). Snake envenomations have been a serious yet often overlooked public health threat especially in tropical and subtropical countries, including Southeast Asia (Kasturiratne et al., 2008). The incidence of snakebite is high in India. Apart from mortality, the morbidity is due to various complications. 
Approximately 10000 to 50000 snakebite related deaths occur in India each year (McNamee, 2001). In this review was planned to document the medicinal plants used for the treatment of venomous snakebites in throughout the India by rural or tribal peoples.

\section{OVERVIEW OF AN ETHNOBOTANY}

Ethnobotany is the study of how people of a particular culture and region make use of indigenous plants. Since their earliest origins, humans have depended on plants for their primary needs and existence. Plants provide food, medicine, shelter, dyes, fibers, waxes, latex, oils, soaps, resins, gums, tannins, and even contribute a major part to the air we breathe. Examining human life on earth requires understanding the role of plants in historical and current day cultures. (Nasab Khosravi, 2014). Throughout time, countless peoples have tested and recorded the usefulness of plants. Those plants with beneficial uses were kept and utilized. Our cultures evolved by passing from generation to generation ever more sophisticated knowledge of plants and their usefulness. Even today, we depend upon plants and their important medicinal properties for treating the diseases. Hence, documentation of native medicinal knowledge of plant species has contributed to a number of modern drug formulations for primary healthcare (Cox, 2000; Bibi et al., 2014). Medicinal plants are a major source of bioactive compounds that help directly in the handling of ophidian envenomation, or ultimately, as supplements to conservative serum therapy. Thus, plant extracts are a expensive substitute, used either alone or in combination with other agents, when antisera are not available in emergency situations.

Investigation on the conventional use of medicinal plants has achieved significant contemplation within the scientific community in recent years; about $25 \%$ of the drugs prescribed worldwide come from plants (Rates, 2001; Jabbar et al., 2007). The conventional system of medicine could not be the entire solution for various human pathological conditions, whereas drug discovery from side to side ethnobotanical study has been found to be one of the most reliable approach and even today this area holds assure for its significant potential (Redizic, 2007; Fabricant and Farnsworth, 2001). Since ancient times, plants have been used for treatment of various diseases. The conventional systems of medicine, together with folklore systems, continue to serve a large portion of inhabitants, particularly in rural and tribal areas despite the advent of modern medicine.

\section{INDIAN SUBCONTINENT}

India is the seventh largest country by the area belonging in South Asia and it has a wide variety of medicinal plants growing under various geographical and ecological conditions. Over 1500 species out of about 15,000 privileged plants species in India have been reported to have medicinal uses (Kosalge \& Fursule, 2009). India is composed of 29 states and seven union territories comprising a total area of $3,287,263 \mathrm{~km}^{2}$. Indians speak a variety of languages, which include 23 regional languages (Assamese, Bengali, Bodo, Dogri, Gujrathi, Kannada, Kashiri, Kokborok, Konkani,
Maithili, Malayalam, Manipuri, Marathi, Mizo, Nepali, Odia, Punjabi, Sanskrit, Santali, Sindhi, Tamil, Telugu, and Urdu). Moreover, there are many more local or tribal dialects spoken by Indians. India is home to different ethnic groups comprising 5.4 crores of indigenous peoples living in various territories, having diverse cultures, religious rites, and food traditions that separate them from each other. These people also have a healthy awareness of traditional medicine, especially herbal and folk medicine for treatment in snakebites (Harsha et al., 2002; Parinitha et al., 2005). Traditional herbalists function closer to the people, taking improvement of the biodiversity of plant species in such areas to cure various diseases and ailments (Houghton \& Osibogun, 1993).

\section{SNAKES OF INDIA}

Snakes have been used to represent war and peace, love and hate, God and devil, as well as life and death; many times they have been used as opposing symbols within the same civilization (Kini and Fox, 2013). Snakebites represent a severe medical, social, and economic challenge in many parts of the world, chiefly in tropical and subtropical nations. Majority of the world's hazardous snakes are found in developing countries, where access to treatment is limited. It is estimated that about 2 million people are bitten annually, resulting in up to $1,25,000$ deaths, and $4,00,000$ permanent disabilities from severe complications, which may lead to amputation (Jager, 2015). Snake venoms are one of the most intense "mysterious" biological fluids within class Mammalia, having complex medical effects owing to the presence of complex mixtures of proteins and peptides and they contain at least 25 enzymes (Zelanis Tashima, 2015; Russell, 1980; Tu, 1988). There are many potential effects in humans following envenoming by snakes, but just a few extensive categories are of major clinical significance such as systemic myolysis flaccid paralysis, coagulopathy and hemorrhage, cardiotoxicity, renal damage and failure, and local tissue injury at the bite site. Sometimes, it causes secondary effects such as potential morbidity and mortality (White, 2005).

\section{SNAKEBITES TREATMENT IN INDIA}

The treatment of snakebite is as variable as the bite itself. The only available treatment is the usage of antivenom against snakebite. The first antivenom (called an anti-ophidic serum) was developed by Albert Calmette, a French scientist of the Pasteur Institute in 1895, against the Indian cobra (Naja naja). Antivenom binds to and neutralizes the venom, stopping further damage, but do not reverses the damage already done. Some individuals may react to the antivenom with immediate hypersensitivity reactions. Other alternative treatment involves the usage of folk and traditional medicines in snake bites. Medicinal herbs are the local heritage in the global importance. Various plants have been used against snake bite, in folk and traditional medicine (Ramaswamy et al., 2018). Currently, a large number of plants and plant materials are being screened for pharmacological activities especially those used in traditional or folk medicine against different diseases. 
Over the years, many attempts have been made for the development of snake venom antagonists especially from plant sources in spite of the existence of antiserum. Many Indian medicinal plants or plant materials are recommended for the treatment of snakebite and some are tested, but so far no systematic analysis has been done (Harsha et al., 2002; Parinitha et al., 2005; Samy et al., 2008; Bhandary, 1996).

\section{PROCEDURE FOR REVIEW OF THIS WORK}

In this systematic review, we assemble information on medicinal plants that are grown and utilized in various rural areas of India for treatment of venomous snakebites. As this is a detailed inspection, this work also carried out an appraisal of plants used in treatment of snakebite poisoning throughout the India. This paper helps readers to find out more about these plants. The suitable literature was reviewed such as technical studies published in journals, and reports, and we searched for relevant information through various electronic databases (Science Direct, MEDLINE, Scopus and Google Scholar) using keywords such as "medicinal plants"; "snakebite"; "ethnobotany or ethnopharmacology or indigenous or Indian" and "survey". It is not possible to incorporate all the information about use of medicinal plants for snakebite treatment, so this work chose to focus on information that is easily accessible to researchers. In the past few decades; different ethnic communities have tried to record traditional and tribal knowledge related to medicinal plants.

However, in most cases this information has yet to be made available to the modern world. A list of medicinal plants was produced, showing biological sources, family, part(s) used, method of preparation, and reference(s). In this review, the precision of botanical identification of plants are obtained from the original sources. While preparing the list of medicinal plants, the following points were considered: biological source(s), family, local name(s) part(s) used, method of preparation, and reference(s).The methodology of preparations depends on the accessibility of plant part(s) and necessity of utilization. Often, the preparation was done by the crushing of plant with the help of stone or a wooden piece, and making juice or paste that will be applied on the affected area; sometimes they are also given orally.

\section{INDIAN SYSTEM OF MEDICINE}

In India, there is a group of people known as "Vaidya" (a doctor of herbs, compounder of medicinal preparations such as Churna, Pills, Syrup, Asava, Aristha, Taila), and elderly persons with folk knowledge about the uses of various house hold spices and herbs. Their native beliefs, skills, and cultural practices concerned with people's health are useful in curing various diseases. Some elderly women with expertise in delivering babies have proficient knowledge about folk medicines for facing day to day health problems, especially among puberty girls, lactating mothers, and pregnant women. As per Indian beliefs, Mother Nature nurtures us. Hippocrates also stated that "Nature cures, not the physician." Plants are rich sources of medicinal compounds by which we can cure a variety of diseases, as well as maintain and improve our health (Naik et al., 2014). Ayurveda states that each and every plant has medicinal use; you just need to find the right person to show that. Owing to the various undesirable effects of some modern day drugs, an increasing number of people from both developed and developing countries have turned to medicinal plants (Patel et al., 2010). There is an extraordinary thinking that understanding knowledge is the key for any revolution. India is a mega diverse nation, home to approximately $10 \%$ of the world's species. For the past several thousands of years, India has nurtured a rich cultural heritage, and large numbers of Indians have used a variety of plants through their rituals and cultural activities. Unfortunately, because of the sudden huge increase in population, negligent behavior toward environ-mental care guidelines, and global climate change, so many species are now on the verge of vanishing. This has had a strong effect on the food chain, standard of living, and cultural practices, rituals of thousands of Indians. To maintain biodiversity, many conservation organizations in India are working to alleviate this trend.

\section{FAMILY WISE LIST OF MEDICINAL PLANTS USED FOR TREATMENT OF SNAKEBITE IN INDIA}

\section{Fabaceae}

\section{Abrus precatorius Linn.}

The $2-3 \mathrm{~g}$ of fresh leaves or roots with seeds are made into paste and consumed along with cold water or cow's milk. Two times a day for 5-7 days to cure any poisonous bite, as well as root powder applied topically (Vijayagiri \& Mamidala, 2012).

\section{Albizia lebbeck Benth.}

Paste of bark or leaves or flower or whole plant was used to treat the poisonous bites (Khalkho et al., 2015; Sahu et al., 2014).

\section{Butea monosperma Taub.}

Bark paste applied on swelling. Paste of one seed in 10 $\mathrm{mL}$ of lemon juice is given orally to treat (Khan et al., 2014).

\section{Clitoria ternatea Linn.}

The root extract is taken along with the root of $A$. indica and Rauwolfia serpentine (Sarkhel, 2014).

\section{Desmodium gangeticum (Linn.)}

Half cup root decoction is taken orally (Mathur and Joshi, 2013).

\section{Mucuna pruriens (Linn.)}

Aqueous extract of root is given orally for twice a day (Kunjam et al., 2013).

\section{Tephrosia purpurea Pers.}

Root decoction along with black pepper is prepared and taken orally for 7 days (Sahu et al., 2014).

\section{Uraria picta Desv.}


Leaf paste or root decoction is given twice daily (Jain and Singh, 2010)

\section{Euphorbiaceae}

\section{Acalypa indica Linn.}

Leaf paste applied over the bitten part or paste smeared on spot of bite for 3 to 4 days (Lal and Singh, 2012).

\section{Emblica officinalis Gaertn.}

Root extract is given orally along with black pepper. Leaf juice as well as stem infusion is given orally (Sarkhel, 2014).

\section{Euphorbia hirta Linn.}

Latex or whole plant, decoction given orally (Yabesh et al., 2014).

\section{Euphorbia neriifolia Linn.}

Latex is applied locally. Root is used with black pepper (Sarkhel, 2014).

\section{Acanthaceae}

\section{Acanthus ilicifolius Linn.}

For dressing snakebite crushed fruits are used (Ravindran et al., 2005).

\section{Andrographis echioides Nees}

Paste of whole plant is given orally with water. It is also applied externally (Alagesaboopathi, 2013).

\section{Andrographis lineate}

Paste of leaves is applied externally. About $30 \mathrm{~g}$ of whole plant paste is directly administered orally (Alagesaboopathi, 2013).

\section{Rhinacanthus nasutus Kurz}

Fresh leaves are taken orally as well as the paste of the leaf is applied externally (Basha, 2012).

\section{Amaranthaceae}

\section{Achyranthes aspera Linn.}

The whole plant extract or root extract is given orally as well as the paste obtained from the root has been used for 3 weeks (Hiremath and Taranath, 2010).

\section{Amaranthus viridis Linn.}

Leaves or stem paste are applied externally (Basha, 2012).

\section{Ranunculaceae}

\section{Aconitum balfourii Muk.}

Tuber paste used externally and internally (Negi et al., 2010).

\section{Araceae}

\section{Acorus calamus Linn.}

Rhizomes are crushed to paste and given with warm water as well as applied externally (Samy et al., 2008).

Arisaema tortuosum (Wall.) Schott
Paste of the tuber in applied. Infusion of fresh bulb is taken orally thrice a day(Mathur and Joshi, 2013).

\section{Sauromatum venosum (Ait.) Kunth}

The paste of tuber is applied on the affected part (Selvanayagam et al., 1995).

\section{Adiantaceae}

\section{Adiantum lunulatum Linn.}

Rhizome powder used for snake bite (Padal et al., 2013).

\section{Adiantum philippense Linn.}

Powder of rhizome is used (Malviya et al., 2012).

\section{Rutaceae}

\section{Aegle marmelos (Linn.)}

Decoction or extract for twice a day upto 5 days of the leaves is given orally or root bark extract is administered internally for every 4 h up to 3 days (Samy et al., 2008).

\section{Murraya paniculata (Linn.) Jack.}

Infusion prepared from shadily dried root or leaf powder and administered orally for every $1 \mathrm{~h}$ up to 2 days (Alagesaboopathi, 2013).

\section{Amaranthaceae}

\section{Aerva lanata (L.) Juss}

Juice is prepared and taken orally for 11 days (Selvanayagam et al., 1995).

\section{Achyranthes aspera Linn.}

The whole plant extract or root extract is given orally as well as the paste obtained from the root has been used for 3 weeks (Hiremath and Taranath, 2010).

\section{Alternanthera sessilis (Linn.)}

External application of stem and leaf paste is used (Selvanayagam et al., 1995).

\section{Amaranthus spinosus Linn}

Paste of leaves is applied locally (Selvanayagam et al., 1995).

\section{Amaranthus viridis Linn.}

Leaves or stem paste are applied externally (Basha, 2012).

\section{Ranunculaceae}

Aconitum balfourii (Bruhl) Muk.

Tuber paste used externally and internally (Negi et al., 2010).

\section{Adiantaceae}

\section{Adiantum philippense Linn.}

Powder of rhizome is used (Malviya et al., 2012).

Adiantum lunulatum Linn.

Rhizome powder used for snake bite (Padal et al., 2013).

Rutaceae 


\section{Aegle marmelos Correa}

Decoction or extract for twice a day upto 5 days of the leaves is given orally or root bark extract is administered internally for every $4 \mathrm{~h}$ up to 3 days (Samy et al., 2008).

\section{Murraya paniculata (Linn.) Jack.}

Infusion prepared from shadily dried root or leaf powder and administered orally for every $1 \mathrm{~h}$ up to 2 days (Alagesaboopathi, 2013).

\section{Asteraceae}

\section{Ageratum conyzoides Linn.}

Paste of leaf with rhizome of Zingiber officinale is used (Jeetendra and Kumar, 2012).

\section{Eclipta alba (Linn.) Hassk.}

Whole plant juice is given orally for 14 days (Alagesaboopathi, 2013).

\section{Eclipta prostrata Linn.}

Leaf paste is applied externally (Alagesaboopathi, 2013).

\section{Tridax procumbens Linn.}

The leaves are crushed and the juice is dripped on the wound of snakebite. Juice is taken orally after its dilution with some quantity of water (Marandi et al., 2015).

\section{Alangiaceae}

\section{Alangium salvifolium (Linn.f) Wang.}

About $15 \mathrm{~g}$ of bark, ground with 10-12 black peppers and mixed with $60 \mathrm{~g}$ animal fat, is given every $2 \mathrm{~h}$ to cure snakebite. Root bark decoction is given internally to treat (Rao and Sunitha, 2011).

\section{Loganiaceae}

\section{Strychnos nux-vomica Linn.}

Root bark juice in cow's milk is externally rubbed 3-4 times a day, to treat. The seed powder is also used (Samy et al., 2008).

\section{Apocynaceae}

\section{Tabernaemontana divaricata Linn.}

The extract of the seed is given as well as crushed, paste applied on bitten area (Bhat et al., 2012).

\section{Alstonea scholaris Linn.}

Bark decoction given orally (Khalkho et al., 2015).

\section{Alstonia venenata R.Br.}

Tablets made from paste of stem bark are taken with cow's urine. Decoction also taken orally (Thirumalai et al., 2010).

\section{Holarrhena antidysentrica Wall}

The root is crushed and applied as well as paste is taken orally with water (Jeetendra and Kumar, 2012).

\section{Nerium indicum Mill.}

The root is crushed with roots of Capparis sepiaria and Datura innoxia, and paste applied externally thrice for 5 days (Khan et al., 2014).

\section{Caesalpiniaceae}

\section{Caesalpinia bonduc Linn.}

Seeds paste applied externally for 2 weeks (Samy et al., 2008).

\section{Cassia alata Linn.}

Paste of leaves is applied externally as well as given orally (Samy et al., 2008).

\section{Cassia fistula Linn.}

The paste and decoction of root bark with black pepper is given orally. Paste of stem bark applied on bitten place (Bhat et al., 2012).

\section{Cassia tora Linn}

Root paste and leaf decoction is applied externally for 14 days (Alagesaboopathi, 2013).

\section{Menispermaceae}

\section{Tinospora cordifolia}

Stem juice or leaf juice along with garlic paste is applied on the spot and also taken orally for 3 to 4 days (Sarkhel, 2014).

\section{Cissampelos pareira Linn}

Root paste with long pepper is prescribed once daily for 5 days (Kumar and Choyal, 2012).

\section{Cocculus villosus DC.}

The root bark extract is given internally and applied (Jeetendra and Kumar, 2012).

\section{Asclepiadaceae}

\section{Tylophora indica (Burm. f.) Merr.}

Paste of leaf and root is mixed with equal amount of root paste of Rauvolfia serpentina and applied externally on the spot as well as leaf juice alone is also taken internally (Alagesaboopathi, 2013).

\section{Calotropis gigantea}

Root bark is ground into paste and made into pills $n$ given orally (Rao and Sunitha, 2011).

\section{Gymnema sylvestre Retz.}

Root Tincture or leaf powder taken orally for 4 days (Nagaraju and Rao, 1990).

\section{Hemidesmus indicus Linn.}

Aqueous extract of root is prepared in water and given orally, and root paste is applied two or three times a day (San et al., 2011).

\section{Liliaceae}

\section{Allium cepa Linn.}

Paste taken from fresh skin bulb for external application for 5 days (Samy et al., 2008). 


\section{Allium sativum Linn.}

Bulb is made into paste and given orally (San et al., 2011).

\section{Gloriosa superb Linn.}

Root paste or tuber paste is applied externally for 2 to 5 days (Samy et al., 2008).

\section{Meliaceae}

\section{Azadirachta indica}

Decoction or paste is prepared and given orally for 7 days (Sarkhel, 2014).

\section{Soymida febrifuga Juss.}

Fresh bark of this plant together with root of H.pubescens are made into paste, and mixed with drinking water, given orally three times a day for 3 days (Kunjam et al., 2013).

\section{Scrophulariaceae}

\section{Bacopa monnieri}

Juice mixed with castor oil is applied externally to treat. Leaf powder decoction mixed with hot cow's milk taken orally (Sarkhel, 2014).

\section{Verbascum Thapsus Linn.}

The infusion of whole plant is given (Kumar and Choyal, 2012).

\section{Caricaceae}

\section{Carica papaya Linn.}

Unripped fruit of Carica papaya is taken and the skin is removed by slicing. Salt is then rubbed over it. The fruit

\section{REFERENCES}

1. Alagesaboopathi C. Ethnomedicinal plants used for the treatment of snake bites by Malayali tribals and rural peoplein Salem district, Tamilnadu, India. Int J Biosci 2013; 3:42-53.

2. Basha SK. Traditional use of plants against snakebite inSugali tribes of Yerramalais of Kurnool district, AndhraPradesh, India. Asian Pacific J Trop Biomed 2012; 2:S575-9.

3. Bhandary MJ, Chandrashekar KR, Kaveriappa KM. Ethnobotany of Gowlis of Uttara Kannada District, Karnataka. J Ethnopharmacol, 1996; 12:244-9.31.

4. Bhat P, Hegde G, Hegde GR. Ethnomedicinal practices indifferent communities of Uttara Kannada district of Karnataka for treatment of wounds. J Ethnopharmacol2012; 143:501-14.63.

5. Bibi S, Sultana J, Sultana H, Malik RN. Ethnobotanical uses of medicinal plants in the highlands of Soan Valley, Salt Range, Pakistan. J Ethnopharmacol, 2014; 155:352-61.

6. Calixto JB. Twenty five years of research on medicinal plants in Latin America: a personal review. J Ethnopharmacol, 2005; 100:131-4.

7. Cox PA. Will tribal knowledge survive the millennium. Science, 2000; 287:44-5.

8. Fabricant DS, Farnsworth NR. The value of plants used in traditional medicine for drug discovery. Environ Health Perspect (Suppl), 2001; 109:69-75

9. Harsha VH, Hebbar SS, Hedge GR, Shripathi V. Ethnomedical knowledge of plants used by Kunabi tribe of Karnataka in India. Fitoterapia, 2002; 73:281-7.

10. Hiremath VT, Taranath TC. Traditional phytotherapy for snake bites by tribes of Chitradurga District, Karnataka, India. Ethnobot Leaflets 2010; 14:120-5. is then placed over the bite with sliced portions in contact with the bite and bandaged. Few drops of latex are applied to wound due to snakebite for quick healing (Khan et al., 2014).

\section{Costaceae}

\section{Costus speciosus Koen}

Rhizome and root paste is used internally and externally (Kumar and Choyal, 2012).

\section{CONCLUSION}

One valuable gift to human health is provided by nature in the form of medicinal plants in the locality and one of the significant ways in which humans directly reap the benefits provided by biodiversity. India has long history of medicinal plant utilization in traditional and tribal culture. From the present review, a total of 67 species from 24 plant families have been used against snakebites, as reported by different ethnobotanical investigations mostly carried out during the past few years in India. In this review, we focused on the collection of data for the most frequently used plants in snakebite treatment. This work tried to be the most comprehensive review to date, and it shows striking similarities between medicinal plant uses in different nations. Thus, by triangulation, it is probably still possible to document most of the knowledge, but further research should continue, especially in areas within nations that have received less attention. Ethnobotanical investigation of drug discovery has been found to be one of the most reliable approaches toward use of medicinal plans for treatment of various conditions, and even now, there are still many more things for us to discover.

11. Houghton PJ, Osibogun IM. Flowering plants used against snakebite. J Ethnopharmacol, 1993; 39:1-29.23.

12. Jabbar A, Zaman MA, Iqbal Z, Yaseen M, Shamim A. Anthelmintic activity of Chenopodium album (L) and Caesalpinia crista (L) against trichostrongylid nematodes of sheep. J Ethnopharmacol, 2007; 114:86-91.

13. Jager AK. Plant-based treatment of snakebites. Indian J Tradit Knowl 2015; 14:571-3.

14. Jain SP, Singh J. Traditional medicinal practices among thetribal people of Raigarh (Chhatisgarh), India. Indian J Nat Prod Resour 2010; 1:109-15.

15. Jeetendra S, Kumar AD. Ethno medicinal plants used by tribal communities for the treatment of snakebite in West Nimar, MP, India. ISCA J Biol Sci 2012; 1:77-9.59.

16. Kasturiratne, A., Wickremasinghe, A.R., de Silva, N., Gunawardena, N.K. and Pathmeswaran, A. (2008). The global burden of snakebite: a literature analysis and modelling based on regional estimates of envenoming and deaths. PLoS Med 5: 218.

17. Khalkho AS, Sahu PR, Kumari S, Alam S. Studies onethnomedicinal uses and formulation of herbal drugs from medicinal plants of Ranchi District-a survey. Am J Ethnomed2015; 2:284-96.55.

18. Khalkho AS, Sahu PR, Kumari S, Alam S. Studies on the medicinal uses and formulation of herbal drugs from medicinal plants of Ranchi District-a survey. Am J Ethnomed2015; 2:284-96.

19. Khan AV, Ahmed QU, Khan MW, Khan AA. Herbal cure for poisons and poisonous bites from Western Uttar Pradesh, India. Asian Pacific J Trop Dis 2014; 4:S116-20.67. 
20. Kini RM, Fox JW. Milestones and future prospects in snakevenom research. Toxicon, 2013; 62:1-2.

21. Kosalge SB, Fursule RA. Investigation of ethnomedicinal claims of some plants used by tribals of Satpuda Hills in India. J Ethnopharmacol, 2009; 121:456-61.

22. Kumar N, Choyal R. Traditional phytotherapy for snake bitesby the local rural people of Hamirpur district in Himachal Pradesh (India). Biol Forum 2012; 4:98-106.60.

23. Kunjam SR, Jadhav SK, Tiwari KL. Traditional herbal medicines for the treatment of snake bite and scorpion sting by the tribes of South Surguja, Chhattisgarh, India. Med Aromat Plants $2013 ; 2: 120-3$.

24. Lal HS, Singh S. Study of plant biodiversity of Hazaribagdistrict Jharkhand India and its medicinal uses. Biosci Disc2012; 3:91-6.

25. Malviya J, Joshi V, Singh K. Antimicrobial activity of someethno-medicinal plants used by Baiga Tribes from Amarkantak, India. Adv Life Sci Technol 2012; 4:19-26.90.

26. Marandi RR, Britto SJ, Arulappan T. Antivenom herbal formulations used against snakebites by the Oroan tribals of Latehar, Jharkhand. World J Pharmaceut Res 2015; 4:197182 .

27. Mathur A, Joshi H. Ethnobotanical studies of the Tarai region of Kumaun, Uttarakhand, India. Ethnobot Res Appl2013; 11:174-203.

28. McNamee D. Tackling venomous snake bite worldwide. Lancet. 2001; 357:1680.

29. Nagaraju N, Rao KN. A survey of plant crude drugs of Rayalaseema, Andhra Pradesh, India. J Ethnopharmacol1990; 29:137-58.

30. Naik LS, Puttaiah ET, Ananth NB. Ethonobotanical studies of some plants included in folk medicines of Goa. Int $\mathrm{J}$ Basic Appl Sci, 2014; 3:6-13.100.

31. Nasab FK, Khosravi AR. Ethnobotanical study of medicinal plants of Sirjan in Kerman Province, Iran. J Ethnopharmacol, 2014; 154:190-7.

32. Negi VS, Maikhuri RK, Phondani PC, Rawat LS. An inventory of indigenous knowledge and cultivation practices of medicinal plants in Govind Pashu Vihar Wildlife Sanctuary, Central Himalaya, India. Int J Biodivers Sci Ecosyst Serv Manage2010; 6:96-105.

33. Ody P. The complex medicinal herbal. New York: Dorling Kindersley Limited; 1993:132-71.

34. Padal SB, Chandrasekhar P, Vijayakumar Y. Traditional uses of Plants by the tribal communities of Salugu Panchayati of Paderu Mandalam, Visakhapatnam, District, AndhraPradesh, India. Int J Comput Eng Res 2013; 3:98-103.88.

35. Parinitha M, Srinivasa BH, Shivanna MB. Medicinal plant wealth of local communities in some villages in Shimoga Distinct of Karnataka, India. J Ethnopharmacol, 2005; 98:307-12.

36. Patel YS, Joshi EP, Joshi PN. Ethnobotanical study of Tapkeshwari Hill, Bhuj, Kachchh, India. Life Sci Leaflets, 2010; 2:22-31.

37. Ramaswamy M, Duraikannu S, Solaimuthu C, The prevalence of Indian common krait envenomation and its clinical complications among the rural populations of India, Journal of
Drug Delivery and Therapeutics. 2018; 8(2):158-162. https://doi.org/10.22270/jddt.v8i2.1676

38. Rao BR, Sunitha S. Medicinal plant resources of Rudrakodsacred grove in Nallamalais, Andhra Pradesh, India. J Biodivers 2011; 2:75-89.

39. Rashid S, Ahmad M, Zafar M, Sultana S, Ayub M, Khan MA. Ethnobotanical survey of medicinally important shrubs andtrees of Himalayan region of Azad Jammu and Kashmir, Pakistan. J Ethnopharmacol 2015; 166:340-51.

40. Rates SMK. Plants as source of drugs. Toxicon, 2001; 39:603-13.

41. Ravindran KC, Venkatesan K, Balakrishnan V, Chellappan KP, Balasubramanian T. Ethnomedicinal studies of Pichavaram mangroves of East coast, Tamil Nadu. Indian $\mathbf{J}$ Tradit Knowl 2005; 4:409-11.

42. Redizic S. The ecological aspect of ethnobotany andethnopharmacology of population in Bosnia and Herzegovina. Coll Antropol, 2007; 31:869-90.

43. Russell FE. Snake venom poisoning. 18. Philadelphia, PA: J.B. Lippincott; 1980:139-234.

44. Sahu PK, Masih V, Gupta S, Sen DL, Tiwari A. Ethnomedicinal plants used in the healthcare systems of tribes of Dantewada, Chhattisgarh India. Am J Plant Sci2014; 5:1632-43

45. Samy RP, Thwin MM, Gopalakrishnakone P, Ignacimuthu S. Ethnobotanical survey of folk plants for the treatment of snake bites in Southern part of Tamilnadu, India. J Ethnopharmacol 2008; 115:302-12.

46. Sarkhel S. Ethnobotanical survey of folklore plants used in treatment of snakebite in Paschim Medinipur district, West Bengal. Asian Pacific J Trop Biomed 2014; 4:416-20.

47. Selvanayagam ZE, Gnanavendhan SG, Balakrishna K, RaoRB. Antisnake venom botanicals from ethnomedicine. J Herbs Spices Med Plants 1995; 2:45-100.

48. Sen S, Chakraborty R, De B, Devanna N. An ethnobotanical survey of medicinal plants used by ethnic people in Westand South district of Tripura, India. J For Res 2011; 22:417-26.

49. Thirumalai T, Elumalai EK, Therasa SV, Senthilkumar B, David E. Ethnobotanical survey of folklore plants for the treatment of jaundice and snakebites in Vellore districts ofTamilnadu, India. Ethnobot leaflets 2010; 14:529-36.50.

50. Tu AT. Snake venoms: general background and composition. In: Venoms: chemistry and molecular biology. New York: Jon Wiley \& Sons; 1988:1-19.

51. Vijayagiri RC, Mamidala E. Ethnobotanical investigations among traditional healers in Warangal district of Andhra Pradesh, India. Pharmacogn J 2012; 4:13-7.41.

52. White J. Snake venoms and coagulopathy. Toxicon, 2005; 45:951-67.

53. WHO. Traditional medicine strategy 20022005.WHO/EDM/TRM/2002.1. Geneva, Switzerland: World Health Organisation; 2002.

54. Yabesh JM, Prabhu S, Vijayakumar S. An ethnobotanical study of medicinal plants used by traditional healers in silent valley of Kerala, India. J Ethnopharmacol2014; 154:774-89.

55. Zelanis A, Tashima AK. Unraveling snake venom complexity with 'omics' approaches: challenges and perspectives. Toxicon 2014; 87:131-4 